\title{
Internalist Foundationalism and the Sellarsian Dilemma
}

(Ali Hasan, Res Philosophica 90(2), 171-184, 2013)

\begin{abstract}
According to foundationalism, some beliefs are justified but do not depend for their justification on any other beliefs. According to access internalism, a subject is justified in believing some proposition only if that subject is aware of or has access to some reason to think that the proposition is true or probable. In this paper I discusses a fundamental challenge to internalist foundationalism often referred to as the Sellarsian dilemma. I consider three attempts to respond to the dilemma - phenomenal conservatism, BonJour's classical foundationalism, and Fumerton's classical foundationalism. I argue that, of these three, only the last seems to avoid getting impaled on one or the other horn of the dilemma. I end by responding to some concerns with Fumerton's account.
\end{abstract}

According to foundationalism, some empirical beliefs are noninferentially justified or foundational: they are justified but do not depend for their justification on any other empirical beliefs. According to access internalism (simply "internalism" in what follows), a subject is justified in believing some proposition only if that subject is aware of or has access to some reason to think that the proposition is true or probable. ${ }^{1}$ The internalist foundationalist is confronted with the formidable task of providing an account of foundational belief that satisfies this internalist requirement. In this paper we will take a careful look at a famous dilemma for internalist foundationalism that is often referred to as the Sellarsian dilemma. ${ }^{2}$ Its proponents apparently intend the dilemma to be a clearly fatal or decisive argument, or at least one for which there seems to be no clear response that is not vulnerable to a dilemma of essentially the same form, so that we might as well give up trying. ${ }^{3}$ I consider three attempts to respond to the Sellarsian dilemma -

\footnotetext{
${ }^{1}$ According to mentalism or internal state internalism, justification is essentially a function of, or supervenes on, the subject's mental states, and in this sense it is "internal" or "inside" the subject. I will be concerned here with access internalism or awareness internalism, and will say nothing about mentalism.

${ }^{2}$ See Sellars (1963, Part I), and (1975). BonJour (1978, 1985) presents the dilemma in a clearer, more commonly repeated form.

${ }^{3}$ See BonJour (1978) and (1985, Chapter 4); Williams (2005).
} 
phenomenal conservatism, BonJour's classical foundationalism, and Fumerton's classical foundationalism. I argue that, of these three, only the last seems to avoid getting impaled on one or the other horn of the dilemma. I end by responding to some concerns with the Fumertonian account.

\section{The Sellarsian Dilemma}

When asked what it is that can justify a foundational belief, or provide the subject with reason or evidence in favor of its truth, internalist foundationalists appeal to nondoxastic states or cognitive acts. This might be a relevant experience, awareness, appearance, or apprehension of some kind. For now, let us call these alleged justifiers “direct apprehensions."

The Sellarsian dilemma can be applied to such direct apprehensions: On the one hand, they might be regarded as judgmental acts of some kind, acts involving the assertion or acceptance of a proposition or thought, or at least the categorization of some sensory item or the application of some concept to experience. But while these apprehensions may serve to justify beliefs, they would surely need justification themselves. Even if an apprehension is not strictly speaking a propositional awareness that something is so-and-so, or that some fact obtains, so long as it involves the application of some concepts to experience, that application must be justified or rational if anything based on it is to be justified as well. And it is not enough for justification that the proposition apprehended happen to be true, or that the concepts or categories applied happen to be accurate; if it were, there would be no clear reason not to say that the original allegedly justified belief could be justified by being true or likely without relying on any direct apprehension at all. On the other hand, the direct apprehensions might be regarded as entirely nonjudgmental and nonconceptual, involving no acceptance of propositions and no categorization or application of concepts. 
While these apprehensions do not require or even admit of justification, the problem here is that they also don't seem to provide a reason or justification for propositional items like beliefs. ${ }^{4}$ Therefore, the foundationalist's direct apprehensions cannot serve as foundations of knowledge or justified belief.

The propositional or conceptual horn of the dilemma is reasonable enough, if understood as the claim that the justification of a propositional apprehension requires a reason for accepting the proposition apprehended as likely to be true; and if this reason is in turn taken to be propositional, then we're off on a regress. If this regress stops sooner or later with a nonpropositional apprehension, then we face the nonpropositional horn of the dilemma. Why should we think that this horn is true? Why can't nonpropositional experiences or apprehensions justify beliefs? It might be tempting to defend this horn as follows. (a) Only some reason to think a proposition likely to be true that $\mathrm{S}$ has cognitive possession of or cognitive access to can justify a belief in that proposition. (b) Only something that can stand in evidential or epistemic relations to something propositional can count as such a reason. (c) Only something propositional (or at least something that involves categorization or the application of concepts, which perhaps can be regarded as implicitly propositional) can stand in evidential or epistemic relations. Therefore, only something propositional, like a belief, can justify a belief.

The internalist is committed to (a), and (b) is arguably true on any plausible definition of a reason. But why should we think (c) true? Coherentists like Sellars, Davidson, McDowell, and BonJour (before the latter's conversion to foundationalism) hold something like it. ${ }^{5}$ For example, consider a famous passage from Davidson:

\footnotetext{
${ }^{4}$ See, for example, BonJour $(1985,78)$, Davidson $(1983,428)$, McDowell $(1994,7)$. For a recent defense of this horn, see Williams (2005).

${ }^{5}$ See, for example, BonJour (1985, 78), Davidson (1983, 428), McDowell (1994, 7).
} 
The relation between a sensation and a belief cannot be logical, since sensations are not beliefs or other propositional attitudes. What then is the relation? The answer is, I think, obvious: the relation is causal. Sensations cause beliefs and in this sense are the basis or ground of those beliefs. But a causal explanation of a belief does not show how the belief is justified. ${ }^{6}$

Davidson is right that the relation between the sensation and belief by virtue of which the belief is justified cannot be merely causal. But that there is a causal relation between sensations and beliefs does not rule out that there is also a "logical" relation between them, at least in the broad sense of being epistemically or evidentially supportive of the belief. After all, it is commonly thought that for beliefs to be justified inferentially, on the basis of other beliefs, there must be some causal relation obtain between the justified belief and its basis. The real worry seems to be that only something propositional can play the role of a premise in an argument or stand in inferential relations, and only something that can play the role of a premise in an argument for $p$ can stand in epistemically supportive relations to the belief that $p$.

James Pryor thinks something like this is the "real intuitive force" behind the claim that only what is propositional can justify something else that is propositional. ${ }^{7}$ But there are relations that can obtain between propositional and nonpropositional items that are neither causal nor, strictly speaking, inferential: (i) relations of correspondence or descriptive accuracy, and (ii) explanatory relations. First, as Fumerton, BonJour (after his conversion), and Pryor have all pointed out, a relation of correspondence, or descriptive adequacy, can obtain between a belief and one's sensory experience. ${ }^{8}$ When I have a headache, or feel thirsty, and believe that I am having a headache or feeling thirsty, there is a correspondence between the content of my experiences and my belief. Second, Moser

\footnotetext{
${ }^{6}$ Davidson $(1983,428)$.

${ }^{7}$ Pryor $(2005,190)$.

${ }^{8}$ Fumerton (2001, 13-14), BonJour (2001, 30), Pryor (2005, 190-191).
} 
argues that explanatory relations can obtain between propositional and nonpropositional, nonconceptual contents:

Being nonpropositional, one's subjective nonconceptual contents do not themselves explain anything. But they can be explained by a proposition. A general explanation-seeking why-question...relevant to the contents of an experience is: why do these contents exist, or occur as they do?

...[O]ne thing explains another when and only when the former makes it, to some extent, understandable why the latter thing is as it is. ...[W]e can say roughly that a proposition explains certain subjective nonconceptual contents if and only if it makes it, to some extent, understandable why those contents are as they are, or equivalently, why those contents occur as they do. ${ }^{9}$

If scientific hypotheses can explain actual events, facts or states of affairs in the world, and not merely propositions about these events, facts, or states of affairs, then it seems in principle possible for a proposition to explain nonpropositional items. Of course, in the case of scientific explanations, our access to these external world facts and events is at best indirect, involving judgments or propositions regarding them. In contrast, when I am seeking an explanation for my experiential contents being some way, I do not need to formulate judgments about my experiences in order to have access to these contents. Of course, being an explanation is one thing, and being a very good, or best, explanation is quite another. But the point is that it's not implausible that explanatory relations provide a good counterexample to the Davidsonian view that only something that is propositional, or that can play the role of a premise in an argument, can stand in broadly logical, epistemic, or evidential relations to propositions.

However, the proponent of the Sellarsian dilemma might object at this stage that the mere fact that these correspondence or explanatory relations obtain is not sufficient for satisfaction of the internalist requirement. The fact that my belief that there is intelligent life elsewhere in this galaxy is true is not sufficient to justify my belief. Nor is constraining

\footnotetext{
${ }^{9}$ Moser (1989, 92-93).
} 
the content of beliefs to the contents of my experiences enough on its own; the fact that there is a red pentagon somewhere in my visual field, when my visual field is filled up with many other colors and shapes, is not sufficient for me to be justified in my belief that there is a red pentagon in my visual field. In fact, I might even be attending to the pentagon itself, and yet not be justified. That my belief just happens to correspond to my experience, or just happens (objectively) to explain why my experiences have the contents that they do, is not enough to yield a justified belief. (The same is true of inferential relations between propositions believed. The fact that some propositions I believe are objectively sufficient to justify others is not enough for me to be justified in the latter beliefs.) Moreover, the addition of a causal condition to the effect that the belief is held because of the relevant experience is not sufficient either, since the causal relation could exist without changing the fact that the subject has no reason to think that the belief is true.

\section{The Appeal to Seemings}

Phenomenal conservatism accepts the following principle of foundational justification:

If it seems to $\mathrm{S}$ that $p$, then, in the absence of defeaters, $\mathrm{S}$ thereby has at least some degree of justification for believing that $p .{ }^{10}$

A "seeming" or "appearance" is a propositional attitude distinct from belief. The proponent of phenomenal conservatism need not accept the access internalist constraint as I have introduced it above, in which case the Sellarsian dilemma won't have much, if any, force against them. ${ }^{11}$ But suppose that a proponent of the view does accept that constraint. Does the view have the resources to block the Sellarsian dilemma? It might seem that the

\footnotetext{
${ }^{10}$ Huemer $(2007,30)$.

${ }^{11}$ In Skepticism and the Veil of Perception (2001), both access-internalism and mentalism seem to be upheld, though the first figures more prominently. See (2001, 21-2 and 104) for what looks like an endorsement of access internalism. See (2001, 178 and 194n3) for an endorsement of mentalism. However, in more recent work (2006), Huemer endorses a specific version of mentalism as opposed to access internalism, claiming that justification supervenes on seemings or appearances.
} 
answer is a straightforward "yes", for if it seems to me that $p$, doesn't it follow that from my perspective $p$ is true? Not so fast. It is uncontroversial that appearances can make a psychological difference to the subject's perspective, and that they can explain why we believe or are inclined to believe certain things, but why should this make an epistemic difference?

Perhaps we can make some progress here if we ask what it is that is in my perspective when it seems to me that $p$. Is it just the proposition $p$ (or perhaps the proposition $p$ is true) that is in the subject's perspective? But if this is all, then it is not clear why this makes an epistemic difference, whereas merely thinking or consciously believing that $p$ (or that $p$ is true) does not. Perhaps the seeming that $p$ involves a distinctive phenomenology, a felt or conscious "pull" or "impulsion" towards the truth of $p .{ }^{12}$ For it to seem to me that $p$ is for me to be aware of or have within consciousness the assertive, striking-me-as-true character of my attitude towards $p$. This idea might be fleshed out in different ways. We might hold that having a seeming that $p$ involves a direct awareness of the distinctive assertive character of the attitude. Alternatively, we might hold that whenever $\mathrm{S}$ has a first-order seeming that $p$, it also seems to $\mathrm{S}$ that it seems to her that $p$, either by S's having a distinct second-order seeming state or a second-order representation as part of the same token state. Whatever the particular proposal, the problem remains: it's not clear why any of this should provide the subject with a reason to think $p$ is true. Suppose that it seems to me that there is a red table here, and so I am in some way aware of its seeming to me that there is a red table here. Does that improve my perspective on the truth of the proposition? Once we bring the fact that I have thus-andsuch seemings into my perspective, perhaps these can provide evidence, but the evidence cuts both ways: various skeptical hypotheses become relevant, and I need some reason to

\footnotetext{
${ }^{12}$ See, for example, Matheson and Rogers (2011, n. 22).
} 
think that the actual truth of a proposition accounts for its seeming to be true better than anything else does. I need some reason to think that the hypothesis that there is a table here accounts for its seeming to me that there is a table here, and that it does so better than the hypothesis that I am hallucinating a table. I need some reason to think that the table's being red accounts for its seeming to me to be red, and does so better than the hypothesis that it is a white table illuminated by red lights. Unless I have some such reason, it is difficult to see why the seeming, of which I am aware, makes any difference to my perspective on the belief's truth.

\section{BonJour}

Fumerton and BonJour provide accounts of foundational empirical beliefs about one's own current experiences, or about the character or contents of one's present mental states. They are both committed to the doctrine of the given, roughly, the view that such beliefs depend for their justification on direct awareness of or acquaintance with reasons for the truth of the relevant beliefs. ${ }^{13}$ However, as we shall see, they disagree on the nature of direct awareness or acquaintance, and on the nature of one's grasp of the connection between the object of direct awareness and the proposition believed.

On BonJour's view, any conscious experience involves a non-apperceptive, "built-in" or constitutive awareness of the specific contents of an experiential state. (I follow BonJour here in using 'contents' very broadly to pick out phenomenal or qualitative features in experience, and not just propositional contents.) On this view, the most basic kind of

\footnotetext{
${ }^{13}$ Some philosophers, like Moser (1989), accept the doctrine of the given, including the claim that external objects cannot be given, but argue that some perceptual beliefs about the external world can be basic or foundational, thereby avoiding the problem that phenomenal beliefs are too scarce to constitute much of a foundation for empirical beliefs in general. Much can be said in support of this kind of view, though there is no space to discuss it here. Even if such a view is preferable, a plausible version of it is likely to take many cues from understanding how beliefs about our experiences are justified.
} 
awareness is constitutive of certain mental states themselves, and what one is aware of is the specific character or content of that mental state. The contents or targets of this awareness may be conceptual or nonconceptual, and so the claim that conceptual items can be given to us in experience is not to be confused with the claim that access to what is given is conceptually mediated and hence not given at all. BonJour insists that it is possible to have a built-in awareness of beliefs, and that this can help account for the possibility of foundational beliefs about the existence and contents of our own (occurrent) beliefs.

Consider, for example, my occurrent, conscious belief that I am eating a sandwich at my desk. One possible view of what makes this belief occurrent or conscious is the apperceptive or higher-order thought theory of consciousness. On this view, to be conscious of my belief that I am eating a sandwich is to have a distinct, second-order state, another, distinct thought or belief, that takes the first-order state as its object: the thought that I am having the belief that I am eating a sandwich at my desk. On BonJour's view, on the other hand, no such second-order state is required to be conscious of the first-order belief.

Rather, an awareness of the occurrent belief's propositional content and assertive character is intrinsic to the state of occurrent belief itself. ${ }^{14}$ A nonconceptual or sensory experience can similarly be treated as a state that involves a constitutive awareness of its own nonconceptual or sensory content.

Fumerton raises the following argument against the coherence of BonJour's view:

It seems to me that for pains and all other sensory states, one can distinguish ontologically and conceptually the experiential state from the awareness of that state. And if one could not, one might face a vicious regress. After all, the experiential state $\mathrm{Y}$, that according to BonJour consists of a sensory content, S plus awareness of said content, A, is itself, presumably, an experiential state. But it cannot, by itself, be an experiential state because such states always have as a constituent awareness of the state. So the original sensory state must now be construed as $\mathrm{S}+\mathrm{A}+\mathrm{A} *$ (where $\mathrm{A}^{*}$ is the awareness of $\mathrm{S}+\mathrm{A}$ ). But $\mathrm{S}+\mathrm{A}+\mathrm{A}^{*}$ can't be an

\footnotetext{
${ }^{14}$ BonJour (2003, 62).
} 
experiential state either without awareness of it, and so on ad infinitum. Every experiential state would seem to involve an infinite complexity. ${ }^{15}$

Fumerton's objection fails because it confuses the relation between an awareness and the state constituted by that awareness on the one hand, with the relation between an awareness and the content of that awareness on the other. Although BonJour is not very explicit about this, on his view an experiential state $\mathrm{Y}$ is constituted by an awareness $\mathrm{A}$ of its content $\mathrm{S}$, not, strictly speaking, by an awareness of the entire state $Y$. The awareness A that constitutes $\mathrm{Y}$ is not part of the content of the state except in the sense that the state is constituted ontologically or metaphysically by that awareness. There is no need for another awareness $\mathrm{A}^{*}$, since $\mathrm{Y}$ need not involve an awareness of $\mathrm{A}$ in addition to $\mathrm{S}$. Perhaps one can also have a more complex state $\mathrm{X}$, constituted by an awareness $\mathrm{A}^{*}$ that is directed at both $\mathrm{A}$ and $\mathrm{S}$, and this would amount to being aware of state Y. ${ }^{16}$ This might be what happens when one is both aware of a pain and aware of being aware of the pain. But having an awareness $\mathrm{A}^{*}$ of $\mathrm{A}$ is not a necessary condition of being aware of $\mathrm{S}$, and so Fumerton's regress is blocked.

BonJour's view thus regards the must fundamental kind of awareness, at least the kind relevant to empirical justification, as built into the nature of all experiences or conscious states. But how are foundational beliefs justified on the basis of this awareness? According to BonJour, S's belief is foundationally justified if and only if (a) $\mathrm{S}$ is constitutively aware of some feature of experience, (b) S attends to that feature, (c) S believes occurrently-and so, on BonJour's view of what this involves, is constitutively aware of-some proposition or thought to the effect that a feature exists or is exemplified by one's experience, and (d) S apprehends or recognizes directly, or is at least in an ideal

\footnotetext{
${ }^{15}$ Fumerton $(2001,72)$.

${ }^{16}$ For a similar suggestion, see Moser (1989, section 2.3.2).
} 
position to apprehend or recognize directly, that the content of the belief "agrees" or "fits" with, or is an accurate conceptual description of, the feature of experience attended to. ${ }^{17}$

Notice that this last condition seems to provide the needed response to the Sellarsian dilemma. Recall that the worry was how to make the object of direct awareness relevant to the truth of one's belief, and bring that relevance into the subject's perspective. Requiring a grasp of the correspondence, agreement, or fit seems just what is needed. There is, however, a serious problem that arises from the fact that BonJour's condition (d) requires a judgmental or propositional recognition of fit. BonJour says that the subject must be in a position to "judge directly" whether there is a fit, or to "recognize directly that a conceptually formulated belief about the state is correct." ${ }^{18}$ The recognition of fit is judgmental or propositional, and not just in the sense that it is a recognition of fit between the propositional content of a belief and something else; the recognition of the fit between the propositional and nonpropositional contents is itself judgmental or propositional. But then it should come as no surprise that BonJour's solution invites pushing the propositional horn of the Sellarsian dilemma. The judgment of fit itself requires justification, and we're off on a regress again.

BonJour anticipates this objection and replies by denying that condition (d) leads to a regress. More specifically, he denies that the recognition or judgment of fit must in turn by justified by something other than the conscious propositional content of the allegedly basic belief and the experiential content that the belief is about, and he complains that insisting otherwise would be an instance of “objectionable overintellectualization.” But BonJour's attempt to block off a regress here is seriously problematic. If the original Sellarsian dilemma has any bite, then surely, so does the dilemma as applied to the

\footnotetext{
${ }^{17}$ See BonJour (2003, 73-4, and 193-4).

18 (2003, 73-4). Emphases added.
} 
judgment of fit. This problem can be made more explicit by exposing a tension between BonJour's conditions for basic beliefs and the conditions for judgments of fit. He wants to allow that a judgment of fit to the effect that some propositional content $p$ fits or accurately describes some experiential content $\mathrm{E}$ can be justified on the basis of one's conscious awareness of both $p$ and $\mathrm{E}$, without the requirement of another, second-order judgment of fit connecting the pair $p$ and $E$ with the first-order judgment of fit about them. But why, then, should he insist that in the simpler case of the first-order basic belief that $p$ about experience $\mathrm{E}$, there must be a judgment of fit? If a higher-order judgment of fit is not required for the justification of the first-order judgment of fit itself, then a judgment of fit should not be required for the basic belief to be justified; if a judgment of fit is required for the basic belief, then a second-order judgment of fit should be required for the fist-order judgment of fit as well. Dropping the requirement entirely results in a view that fails to show how beliefs are justified, while retaining it gets the regress started again. So BonJour has not succeeded in avoiding the dilemma.

\section{A Fumertonian Acquaintance Theory}

According to Fumerton's acquaintance theory, S has a noninferentially justified or foundational belief that $p$ if $\mathrm{S}$ is acquainted with the thought that $p$, acquainted with some fact that corresponds to the thought that $p$ (to simplify discussion, call this the fact that $p$ ) and acquainted with the correspondence between the thought that $p$ and the fact. ${ }^{19}$ Acquaintance is a special, irreducible relation that can hold between the self and a state of, property of, or fact about the self. Though Fumerton takes acquaintance to be fundamentally a relation rather than a feature of or property of a state, like BonJour's

\footnotetext{
${ }^{19}$ Fumerton adds some qualifications to accommodate fallibilism, but these are ignored to simplify discussion. The task of accommodating fallible foundations is a significant challenge. See Fales (1996, 174-80), Fumerton (2010), and Hasan (2013).
} 
"built-in" awareness, acquaintance with a fact is a nonjudgmental, direct or immediate awareness of that fact. Thoughts are non-linguistic properties of the mind or self, and are the primary bearers of truth value; they are true if they correspond to the facts, and false if they fail to correspond to the facts. A fact is a "non-linguistic complex that consists in an entity or entities exemplifying properties." 20

On Fumerton's view, no single act of acquaintance yields justified belief, and the requirement of acquaintance with a correspondence between the fact that $p$ and the thought that $p$ is crucial. If we keep this in mind, Fumerton's response to the Sellarsian dilemma is straightforward. Fumerton could be understood as grasping the non-judgmental or nonconceptual horn of the dilemma, since none of the fundamental acts of acquaintance are themselves judgmental or conceptual in character. However, since a thought, and correspondence with a thought, can be objects or targets of acquaintance, the view avoids the worry that it cannot provide justification. "[W]hen everything constitutive of a thought's being true is immediately before consciousness, there is nothing more that one could want or need to justify a belief..."21 It is tempting to object that multiplying acts of acquaintance cannot conjure up an epistemic property when a single one does not, but as Fumerton points out, that no part of this analysis involves an epistemic property does not entail that the same holds for the whole.

There are, however, at least two apparent problems with Fumerton's acquaintance theory. The first is concerned with the possibility of being acquainted with a relation of acquaintance, and the second with the requirement of acquaintance with a relation of correspondence. The problems point to unintuitive aspects of the theory that, if the theory really is correct, should not strike one as so unintuitive. After presenting each problem, I

\footnotetext{
${ }^{20}$ Fumerton $(1995,73)$.

${ }^{21}$ Fumerton (1995, 74-5).
} 
will respond on behalf of the acquaintance theory. I will end by considering the worry that the account proposed leads inevitably to skepticism.

It seems that any classical view should be able to allow for the possibility that we be acquainted with our being acquainted with something, or aware of our being aware of something, even if we should not expect that appealing to such an awareness is going to persuade those inclined to reject classical foundationalism. Fumerton is quite explicit that he thinks we can be acquainted with our being acquainted with something. ${ }^{22}$ It is intuitive that one can be directly aware of, say, a pain, and intuitive that one can also somehow be directly aware of being directly aware of a pain. A useful analogy is provided by Moser: "Compare the parallel situation where one is so absorbed in what is happening on the movie screen that one is completely unaware of one's watching a movie." ${ }^{23}$ Becoming aware of one's watching a movie is analogous to becoming directly aware of being directly aware of pain. Given Fumerton's view, acquaintance with acquaintance amounts to a direct awareness of a relation between the self or mind on the one hand, and something occurring in the self or mind on the other. This presumably requires being acquainted with the mind or self itself. But it is not at all clear what such an awareness of the mind would be like, and it seems that any view of direct awareness would do well to avoid such commitments as much as possible.

One way to avoid this problem is by accepting BonJour's account of the nature of awareness as built into the conscious state. As already suggested above in responding to Fumerton's criticism of BonJour, to be aware of one's being aware of pain is to have a state with built-in awareness of one's built-in awareness of pain, and this would not require any distinct, direct awareness of the self. The self might simply be understood as the subject of

\footnotetext{
${ }^{22}$ Fumerton $(1995,77)$.

${ }^{23}$ Moser (1989), p. 78.
} 
this state of awareness, and the existence of the self justified on that basis. Alternatively, if one wants to hold onto Fumerton's relational account of acquaintance one could perhaps deny that acquaintance with a complex requires acquaintance with all its constituents, and in particular deny that acquaintance with a complex fact S-being-acquainted-with-F required acquaintance with S. (See Chisholm 1974.) The following analogy might help: I can be directly aware of one line's being longer than another without being aware of the precise length of either, and directly aware of a color's being darker than another without being aware of the specific shade. Might I not similarly be aware of a relation between myself and something else without being directly aware of myself? ${ }^{24}$

The second problem is that many find it difficult to accept that they are ever acquainted with the correspondence between a thought and a fact. There is an intuitive idea of what something like acquaintance with pain is like, and even an intuitive idea of what something like acquaintance with a concept or thought is like. And it is difficult to deny having some understanding of correspondence, the relation that must hold between a thought and something else for that thought to be true. But is one ever acquainted with or directly aware of a relation of correspondence that obtains between a thought and a fact, such as between the thought that one is in pain and the fact that one is in pain? The fact that one can raise serious doubts regarding whether one is ever acquainted with correspondence seems to be a good reason to think that that one is in fact not acquainted with a relation of correspondence.

The acquaintance theorist can raise a number of points that should at least shake one's confidence in such denials. First, it is worth pointing out that verifying that one is

\footnotetext{
${ }^{24}$ BonJour's view, while not committed to the bundle-theory, is compatible with it, while Fumerton's view seems incompatible with the bundle-theory. On the other hand, the relational view can more easily accommodate the possibility of awareness of nonmental entities such as abstract properties and relations, and perhaps concrete external facts. I want to leave open which of these views is correct.
} 
directly acquainted with correspondence is a sophisticated matter. In order to ascertain whether I am acquainted with the correspondence between some fact $\mathrm{F}$ and the thought that $p$, I must be acquainted with the fact of my being acquainted with this particular correspondence relation, acquainted with the thought that I am acquainted with the correspondence between $\mathrm{F}$ and $p$, and acquainted with the correspondence between the former fact and the latter thought! It is no wonder, then, that we will have some difficulty verifying that we are directly acquainted with correspondence, even if and when we are..$^{25}$

Second, while it is possible for one to be convinced, under the influence of a cunning Sellarsian perhaps, that one is not "acquainted with correspondence," this does not raise any serious worries with the view. A subject might understand "acquaintance with correspondence" in some theoretical way and yet simply fail to identify or pick out the right sort of awareness, and be moved by theoretical arguments to deny that one is every acquainted with correspondence. But why should this make any difference to one's perspective on the truth of some proposition in a case where she is directly acquainted with the relevant correspondence, whether she judges that it as an awareness of correspondence or not? Some views might treat this belief to the effect that there is no such acquaintance with correspondence as a defeater or, more plausibly perhaps, as having little or no effect on one's first-order justified belief that $p$. In either case, the acquaintance theorist can insist that acquaintance with correspondence does make the relevant difference to the subject's perspective on the truth.

The reader might at this stage grant that the above replies are adequate, at least for sake of argument, but worry that the account is unlikely to yield much theoretical fruit. It may seem that the requirements for foundational justification are much too demanding,

\footnotetext{
${ }^{25}$ See Gertler $(2011,115-6)$ for a similar suggestion that satisfying the conditions of the acquaintance account is much easier than verifying that you satisfy them.
} 
leading to radically skeptical consequences. While it is rarely presented as an explicit argument against classical foundationalism, this seems to be a major reason for dissatisfaction with the view.

I cannot adequately discuss the threat of skepticism or the theoretical virtues of the acquaintance theory here. But I can say a few things in response that suggest that these worries are not as serious as it may at first seem—or, at the very least, that it would be premature to regard them to be serious without further investigation. First, it should perhaps be an open question whether the skeptical consequences of an analysis of justification should automatically defeat it. As classical foundationalists have often insisted, it is only on the assumption that skepticism is false that we can reject an account of what it is to be justified that leads to it. That assumption may be obviously correct when it comes to belief in the existence of our own experiences, or very simple a priori truths, but belief in the existence of a commonsense world of physical objects is another matter entirely. Second, whether skepticism regarding the external world follows depends a great deal on what one is acquainted with. While there is no room to discuss this here, some endorse the possibility of acquaintance with relations of entailment, explanation, and probability holding between propositions in their accounts of inferentially justified belief. ${ }^{26}$ What emerges is a unified account of inferential and noninferential justification, and depending on what sorts of relations one is acquainted with, the acquaintance theorist might actually be in a unique position to secure access-internalist justification for belief in the external world. Finally, some proponents of acquaintance or direct awareness - most famously, Russell, but more recently, Bealer and BonJour - have appealed to awareness of universals in order to account for the possibility of thought itself, and for knowledge of

\footnotetext{
${ }^{26}$ See BonJour (1998), and Moser (1989).
} 
necessary truths. ${ }^{27}$ Awareness of universals can also play a role in the Fumertonian account of empirical foundations: if a thought involves acquaintance with universals that happen to be instantiated or exemplified by some object or state, then it makes sense that one can directly compare and become acquainted with the correspondence between the two.

Of course, the considerations discussed in the last paragraph, especially towards the very end, are quite controversial and not unproblematic, and I do not claim to have offered any adequate defense of them here. Moreover, acquaintance theorists may not want to commit themselves to all of it. But these considerations serve as a reminder that a theory may have more flexibility, resources, and theoretical advantages than initial appearances suggest. Get acquainted with the acquaintance theory, and you might find it much more plausible than most contemporary epistemologists think.

\section{REFERENCES}

Bealer, G. (1982) Quality and Concept. Oxford: Claredon Press.

BonJour, L. (1978) Can Empirical Knowledge Have a Foundation? American Philosophical Quarterly, 15, 1-13.

BonJour, L. (1985) The Structure of Empirical Knowledge. Cambridge, MA: Harvard University Press.

BonJour, L. (1998) In Defense of Pure Reason. Cambridge, MA: Cambridge University Press.

BonJour, L. (2001) Toward a Defense of Empirical Foundationalism. In M. DePaul (Ed.), Resurrecting Old-Fashioned Foundationalism. Lanham, MD: Rowman \& Littlefield.

BonJour, L. (2003) A Version of Internalist Foundationalism. In L. BonJour and E. Sosa, Epistemic Justification: Internalism vs. Externalism, Foundations vs. Virtues. Malden, MA: Blackwell.

Chisholm, R. (1974) On the Nature of Acquaintance: A Discussion of Russell's Theory of Knowledge. In George Nakhinikian (ed.), Bertrand Russell's Philosophy, London: George Duckworth and Co., Ltd., 47-56.

Davidson, D. (1983) A Coherence Theory of Truth and Knowledge. In D. Henrich (Ed.), Kant Order Hegel. Stuttgart: Klett-Cotta.

Fales, E. (1996) A Defense of the Given. Lanham, MD: Rowman \& Littlefield.

Fumerton, R. (1995) Metaepistemology and Skepticism. Lanham, MD: Rowman \& Littlefield.

\footnotetext{
${ }^{27}$ Russell (1912), Bealer (1982, Ch. 8), and BonJour (1998, Ch. 6)
} 
Fumerton, R. (2001) Classical Foundationalism. In M. De Paul (Ed.), Resurrecting OldFashioned Foundationalism. Lanham, MD: Rowman \& Littlefield.

Fumerton, R. (2010) Poston on Similarity and Acquaintance. Philosophical Studies 147, 379-86.

Gertler, B. (2011) Self-Knoweldge. New York: Routledge.

Hasan, A. (2013) Phenomenal Conservatism, Classical Foundationalism, and Internalist Justification. Philosophical Studies, 162, 119-141.

Huemer, M. (2001). Skepticism and the Veil of Perception. Lanham, MD: Rowman \& Littlefiled

Huemer, M. (2006). Phenomenal Conservatism and the Internalist Intuition. American Philosophical Quarterly, 43(2), 147-58.

Huemer, M. (2007). Compassionate Phenomenal Conservatism. Philosophy and Phenomenological Research, 74(1), 30-55.

Rogers, J. and Matheson, J. (2011) Bergmann's dilemma: exist strategies for internalists. Philosophical Studies, 152, 55-80.

McDowell, J. (1994) Mind and World. Cambridge: Harvard Univerity Press.

Moser, P. (1989) Knowledge and Evidence. Cambridge: Cambridge University Press.

Russell, B. (1912) The Problems of Philosophy. Oxford: Oxford University Press.

Sellars, W. (1963) Empiricism and the Philosophy of Mind. In Science, Perception and Reality. London: Routledge.

Sellars, W. (1975) The Structure of Knowledge. In H. N. Castaneda (ed.), Action, Knowledge, and Reality. Indianapolis: Bobbs-Merrill.

Sosa, E. (2003) Beyond Internal Foundations to External Virtues. In L. BonJour and E. Sosa, Epistemic Justification: Internalism vs. Externalism, Foundations vs. Virtues. Malden, MA: Blackwell.

Williams, M. (2005) Doing without Immediate Justification. In M. Steup and E. Sosa (Eds.), Contemporary Debates in Epistemology. Malden, MA: Blackwell. 